\title{
Prognostic Marker for Severe Acute Exacerbation of Chronic Obstructive Pulmonary Disease: Analysis of Diffusing Capacity of the Lung for Carbon Monoxide (DLCO) and Forced Expiratory Volume in One Second (FEV1)
}

Juwhan Choi

Division of Pulmonary, Allergy, and Critical Care Medicine, Department of Internal Medicine, Korea University Guro Hospital, Korea University College of Medicine, Seoul

Jae Kyeom Sim

Division of Pulmonary, Allergy, and Critical Care Medicine, Department of Internal Medicine, Korea University Guro Hospital, Korea University College of Medicine, Seoul

Jee Youn Oh

Division of Pulmonary, Allergy, and Critical Care Medicine, Department of Internal Medicine, Korea University Guro Hospital, Korea University College of Medicine, Seoul

\section{Young Seok Lee}

Division of Pulmonary, Allergy, and Critical Care Medicine, Department of Internal Medicine, Korea University Guro Hospital, Korea University College of Medicine, Seoul

\section{Gyu Young Hur}

Division of Pulmonary, Allergy, and Critical Care Medicine, Department of Internal Medicine, Korea University Guro Hospital, Korea University College of Medicine, Seoul

\section{Sung Yong Lee}

Division of Pulmonary, Allergy, and Critical Care Medicine, Department of Internal Medicine, Korea University Guro Hospital, Korea University College of Medicine, Seoul

\section{Jae Jeong Shim}

Division of Pulmonary, Allergy, and Critical Care Medicine, Department of Internal Medicine, Korea University Guro Hospital, Korea University College of Medicine, Seoul

\section{Chin Kook Rhee}

Division of Pulmonary, Allergy and Critical Care Medicine, Department of Internal Medicine, Seoul St. Mary's Hospital, College of Medicine, The Catholic University of Korea, Seoul

\section{Kyung Hoon Min ( $\nabla$ minkyunghoon@korea.ac.kr)}

Division of Pulmonary, Allergy, and Critical Care Medicine, Department of Internal Medicine, Korea University Guro Hospital, Korea University College of Medicine, Seoul 


\section{Research Article}

Keywords: COPD, DLCO, FEV1

Posted Date: February 12th, 2021

DOl: https://doi.org/10.21203/rs.3.rs-96162/v2

License: (c) (i) This work is licensed under a Creative Commons Attribution 4.0 International License. Read Full License 


\section{Abstract}

Background: It is important to assess the prognosis and classify patients in chronic obstructive pulmonary disease (COPD) and acute exacerbation of COPD (AECOPD) treatment. Recently, it was suggested that diffusing capacity of the lung for carbon monoxide $\left(D_{\mathrm{LCO}}\right)$ should be added to multidimensional tools for assessing COPD. This study aimed to compare the $\mathrm{D}_{\mathrm{LCO}}$ and forced expiratory volume in one second $\left(\mathrm{FEV}_{1}\right)$ to identify better prognostic factors for admitted patients with AECOPD.

Methods: We retrospectively analyzed 342 patients with AECOPD receiving inpatient treatment. We classified 342 severe AECOPD events using $D_{L C O}$ and $F E V_{1}$. We defined the prognostic factors of severe AECOPD as the length of hospital stay, mortality in hospital, experience of mechanical ventilation, and experience of intensive care unit (ICU) care. We analyzed the prognostic factors by multivariate analysis using logistic regression. In addition, we conducted a correlation analysis and receiver operating characteristic (ROC) curve analysis.

Results: In univariate and multivariate analyses, $D_{\text {LCO }}$ was shown to predict mortality rate (odds ratio = 4.408; 95\% confidence interval, $1.070-18.167 ; P=0.040$ ), experience of ventilator (odds ratio $=2.855$; $95 \%$ confidence interval, $1.216-6.704 ; P=0.016$ ) and ICU (odds ratios $=2.685 ; 95 \%$ confidence interval, 1.290-5.590; $P=0.008)$. However, there was no statistically significant difference in mortality rate when using $\mathrm{FEV}_{1}$ classification $(P=0.075)$. In the correlation analysis, both $\mathrm{D}_{\mathrm{LCO}}$ and $\mathrm{FEV}_{1}$ showed a negative correlation with length of hospital stay. The correlation rate was more pronounced in the $\mathrm{D}_{\mathrm{LCO}}\left(\mathrm{D}_{\mathrm{LCO}} ; B=\right.$ -0.103, $P<0.001)\left(\mathrm{FEV}_{1} ; B=-0.075, P=0.007\right)$. In addition, $\mathrm{D}_{\mathrm{LCO}}$ showed better predictive ability than $\mathrm{FEV}_{1}$ in ROC curve analysis. The area under the curve (AUC) of $\mathrm{D}_{\mathrm{LCO}}$ was greater than 0.68 for all prognostic factors, and in contrast, the AUC of $\mathrm{FEV}_{1}$ was less than 0.68 .

Conclusion: $\mathrm{D}_{\mathrm{LCO}}$ was likely to be as good as or better prognostic marker than $\mathrm{FEV}_{1}$ in severe AECOPD.

\section{Background}

Chronic obstructive pulmonary disease (COPD) is a chronic airway disease defined by persistent respiratory symptoms and irreversible airflow limitation [1-3]. Patients with COPD present with various symptoms, such as cough, sputum, and dyspnea, and these symptoms are closely related to the quality of life and prognosis [4, 5]. The global initiatives for chronic obstructive lung disease (GOLD) reports emphasize treatment based on patient history and symptoms, such as exacerbation history, the modified medical research council dyspnea scale (MMRC), and COPD assessment test (CAT) [6]. Forced expiratory volume in one second $\left(\mathrm{FEV}_{1}\right)$ is still used to grade the severity of airflow obstruction, but the 'refined $A B C D$ assessment tool' excludes $F E V_{1}$ from the criteria for evaluating the 'ABCD' group. This is because the $\mathrm{FEV}_{1}$ value is weakly correlated with the patient's symptoms and health status $[7,8]$. However, pulmonary function tests (PFT) are still important tests for diagnosing and treating COPD in the clinical field. Therefore, we want other PFT factors related to the patient's symptoms and health status rather 
than $\mathrm{FEV}_{1}$. Several studies have shown that the diffusing capacity of the lung for carbon monoxide ( $D_{\mathrm{LCO}}$ ) among the various values of PFT is closely related to patient symptoms, prognosis, and oxygen demand in COPD $[9,10]$. In addition, there was a recent opinion that $\mathrm{D}_{\mathrm{LCO}}$ should be added to multidimensional tools assessing COPD [11]. This study aimed to compare $\mathrm{FEV}_{1}$ and $\mathrm{D}_{\mathrm{LCO}}$ through the prognosis of severe acute exacerbations of COPD (AECOPD).

\section{Method}

\section{Study population}

We retrospectively analyzed the medical records of 342 patients admitted to Korea University Guro Hospital from January 2011 to May 2017. We searched our electronic medical records database with the keywords "COPD" and "Acute exacerbation." This study was approved by the Institutional Review Board of Korea University Guro Hospital. (KUGH16131-002). The requirement for informed consent from the patients was waived due to the retrospective nature of this study by the institutional review committee.

All patients included only patients who were followed up for more than one year in our hospital under the diagnosis of COPD. COPD and airflow limitation were diagnosed by synthesizing patient-reported respiratory symptoms, PFT (the ratio of $\mathrm{FEV}_{1}$ to forced vital capacity (FVC) was less than $70 \%$ in postbronchodilator spirometry), chest image, and patient`s history (smokers with at least ten pack-years of tobacco exposure, etc.) by an experienced pulmonologist [6]. AECOPD was defined as worsening of the patient's respiratory symptoms beyond normal day-to-day variation. Severe AECOPD was defined as 'if the patient needs hospitalization due to AECOPD.' The spirometry data used in the analysis was previously performed in the outpatient clinic during the stable period. Spirometry value that was measured within one year from the hospitalization day were used. Patients were excluded with the following criteria: 1 ) the cause of admission was not AECOPD; for example, acute heart failure, acute pulmonary edema, acute pulmonary embolism, pneumothorax, and arrhythmia (These diseases were excluded through cardiac enzyme, electrocardiogram, echocardiogram and chest image.), 2) the patient had cancer, 3) the patient received a major operation within 3 months, 4) the patient had an acute coronary syndrome, brain hemorrhage, or brain infarction within 3 months, 5) the patient had previously been diagnosed with asthma, and 6 ) the patient had no $D_{\text {LCO }}$ results. All patients were 40 years old or older. We retrospectively analyzed the charts by two experienced pulmonologists to exclude various exclusion factors.

We classified 342 severe AECOPD events using $D_{\text {LCO }}$ and $F E V_{1}$. When the $D_{\text {LCO }}$ value is more than $50(\%$ of predicted value), it is defined as the ' $\mathrm{D}_{\mathrm{LCO}}$ normal group' and when it is 50 (\% of predicted value) or less, it is defined as the ' $\mathrm{D}_{\mathrm{LCO}}$ impaired group' [11]. Likewise, when the $\mathrm{FEV}_{1}$ value is more than 50 (\% of predicted value), it is defined as the ' $F E V_{1}$ normal group' and when it is 50 (\% of predicted value) or less, it is defined as the 'FEV ${ }_{1}$ impaired group' (Figure 1).

\section{Data collection}


We defined the prognostic factors of severe AECOPD as the length of hospital stay, mortality in hospital, experience of mechanical ventilation, and experience of intensive care unit (ICU) care in the hospital. When the patient was hospitalized more than once, only the first hospitalized events were included, and the others were excluded. The following medical data were analyzed: age, sex, smoking history, comorbidities, baseline spirometry, inhaler and oral medication before admission, length of hospital stay, hospital mortality, experience of mechanical ventilation, and experience of ICU care in hospital.

\section{Statistical analysis}

Data were analyzed using SPSS 20 software (SPSS for Windows, SPSS Inc., Chicago, IL, USA). Data are presented as average \pm standard deviation or number (percentage). We performed a statistical analysis in two directions. First, two groups were classified using $\mathrm{D}_{\mathrm{LCO}}$ and $\mathrm{FEV}_{1}$ and analyzed statistically. Continuous variables were compared using the independent $t$-test, and categorical variables were compared using the chi-squared test. We analyzed the prognostic factors (except length of hospital stay) by multivariate analysis through logistic regression. Multivariate analysis was conducted for variables with a $P$-value of less than 0.05 in the univariate analysis, except for baseline spirometry $\left.\left(D_{\text {LCO }} \text { and FEV }\right)_{1}\right)$. Multivariate analysis was conducted using a backward elimination procedure and was assessed by the Hosmer-Lemeshow test.

Second, the linear correlation between spirometry factors ( $D_{\mathrm{LCO}}$ and $\left.\mathrm{FEV}_{1}\right)$ and length of hospital stay were analyzed. In univariate analysis, the correlation coefficients between spirometry factors and length of hospital stay were analyzed using the Pearson correlation analysis. In addition, we performed a multivariate linear regression analysis that included variables with a $P$-value of less than 0.05 in the univariate analysis, except baseline spirometry. In addition, multivariate linear regression analysis was conducted using a backward elimination procedure. In the multivariate analysis, $B$ was the regression coefficient, and a negative sign of the regression coefficient meant that the variables were negatively associated.

Third, we used receiver operating characteristic (ROC) curve analysis to predict the sensitivity and specificity of $\mathrm{D}_{\mathrm{LCO}}$ and $\mathrm{FEV}_{1}$ as prognostic markers in severe AECOPD. A P-value of less than 0.05 was considered statistically significant.

\section{Results}

\section{Characteristics of studied subjects}

Among the 342 events, the $D_{L C O}$ normal group comprised 227 events (the $D_{L C O}$ value was more than $50 \%$ of the predicted value), and 115 in the $\mathrm{D}_{\mathrm{LCO}}$ impaired group. In the $\mathrm{FEV}_{1}$ normal group (the FEV $\mathrm{F}_{1}$ value was more than $50 \%$ of the predicted value), there was 173 events, and the $\mathrm{FEV}_{1}$ impaired group had 169 events. The average age was $71.5 \pm 9.2$ years. A total of 238 (69.6\%) events were male and $104(30.4 \%)$ were female. Sixty-three (18.4\%) events were current smokers and the average pack/year history was 41.3 
\pm 17.1 years. A total of 225 (65.38) events were using inhalers, and $165(48.2 \%)$ were taking respiratoryrelated oral medications. Averaged $\mathrm{FEV}_{1}$ was $1.3 \pm 0.5 \mathrm{~L}(54.0 \pm 19.3 \%)$ and $\mathrm{D}_{\mathrm{LCO}}$ was $10.6 \pm 4.8 \mathrm{~L}(59.3 \pm$ $21.4 \%$ ). (Table 1) In both groups, the average length of hospital stay was $10.0 \pm 5.1$ days. The mortality rate was $11(3.2 \%)$, the experience of ventilator care was 29 (8.5\%), and the experience of ICU care was 39 (11.4\%).

\section{Prognostic factor analysis classified using $\mathrm{D}_{\mathrm{LCO}}$ and $\mathrm{FEV}_{1}$}

When classified through $D_{L C O}$, the $D_{L C O}$ impaired group showed a poor prognosis in all four factors by univariate analysis (Figure 2). When classified through $\mathrm{FEV}_{1}$, the $\mathrm{FEV}_{1}$ impaired group showed a poor prognosis in three factors by univariate analysis (Figure 3 ). However, there was no statistically significant mortality rate when classified as $\mathrm{FEV}_{1}(P$-value $=0.116)($ Figure $3 \mathrm{~B})$.

In multivariate analysis, when classified as $D_{\mathrm{LCO}}$, all three factors showed significant prognostic differences. In severe AECOPD, $\mathrm{D}_{\mathrm{LCO}}$ has been shown to predict mortality rate, ventilator, and ICU possibilities. When classified as $\mathrm{FEV}_{1}$, the experience of mechanical ventilation and ICU showed statistical significance. However, there was no significant difference in mortality rate $(P=0.075)$ (Table 2).

\section{Correlation analysis between spirometer factors and length of hospital stay}

The length of hospital stay of the $D_{\text {LCO }}$ normal group was $7.3 \pm 5.0$ days and the $D_{L C O}$ impaired group was $12.4 \pm 13.2$ days. The length of hospital stay of the $\mathrm{FEV}_{1}$ normal group was $7.7 \pm 5.4$ days and the $\mathrm{FEV}_{1}$ impaired group was $10.4 \pm 11.4$ days. In the Pearson correlation analysis, both $\mathrm{D}_{\mathrm{LCO}}$ and $\mathrm{FEV}_{1}$ showed a negative correlation. The correlation coefficient was more pronounced in the $\mathrm{D}_{\mathrm{LCO}}$ analysis. In multivariate linear regression analysis, both $\mathrm{D}_{\mathrm{LCO}}$ and $\mathrm{FEV}_{1}$ showed a negative correlation. Additionally, the regression coefficient was more pronounced in the $D_{\text {LCO }}$ analysis (Table 3 ).

\section{ROC curve analysis of $\mathrm{D}_{\mathrm{LCO}}$ and $\mathrm{FEV}_{1}$}

When analyzing the sensitivity and specificity using the ROC curve, $D_{L C O}$ showed better predictive ability than $\mathrm{FEV}_{1}$ (Table 4). When analyzing three prognostic factors (mortality in hospital, mechanical ventilation, and ICU care) through ROC curve analysis, area under the curve (AUC) was greater than 0.68 in all cases of $\mathrm{D}_{\mathrm{LCO}}$ (Figure 4). In contrast, the AUCs of $\mathrm{FEV}_{1}$ were below 0.68 in all three prognostic factors. In addition, the sensitivity and specificity of $D_{L C O}$ were more than $64.1 \%$, which was generally higher than $\mathrm{FEV}_{1}$.

\section{Discussion}

This is the first study to compare $\mathrm{FEV}_{1}$ and $\mathrm{D}_{\mathrm{LCO}}$ as prognostic markers in severe patients with AECOPD in Korea. In our study, the factors of prognosis were defined as the length of hospital stay, mortality rate in 
the hospital, experience of ventilation, and experience of ICU care. Classification by $D_{\text {LCO }}$ showed significant differences in all prognostic factors. Classification by $\mathrm{FEV}_{1}$ did not show a statistically significant mortality rate. In the correlation analysis, both $\mathrm{D}_{\mathrm{LCO}}$ and $\mathrm{FEV}_{1}$ showed a negative correlation with the length of hospital stay. The correlation coefficient was more pronounced in the $\mathrm{D}_{\mathrm{LCO}}$ classification. In addition, when analyzing the ROC curve, $\mathrm{D}_{\mathrm{LCO}}$ showed better predictive ability than $\mathrm{FEV}_{1}$. Of course, some odds ratio values were better when classified as $\mathrm{FEV}_{1}$ in our study. However, $\mathrm{D}_{\mathrm{LCO}}$ was better in various analysis methods (correlation analysis, ROC curve analysis), which was likely to be as good as or better than $\mathrm{FEV}_{1}$.

The PFT has various parameters. In general, we used FEV $_{1}$ to grade COPD and select the inhaler. In addition to $\mathrm{FEV}_{1}, \mathrm{D}_{\mathrm{LCO}}$ is an important prognostic factor. In a study of smokers who did not show an obstruction pattern in PFT, a low $\mathrm{D}_{\mathrm{LCO}}$ group showed quickly decreased pulmonary function and COPD progression [12]. Studies have shown that $D_{L C O}$ is a more accurate prognostic factor than $\mathrm{FEV}_{1}$ when assessing postoperative risk $[13,14]$. In addition, $D_{L C O}$ is known to accurately represent the actual emphysema level and performance status $[15,16]$. These results suggest that $D_{L C O}$ can be a good predictor of early pulmonary dysfunction and prognosis.

If we know the prognosis of the patient early, we can focus on high-risk patients and improve the prognosis. The prognostic factors that can be used in the clinic are laboratory findings, scoring systems such as CAT or mMRC, and baseline spirometry $[17,18]$. In some studies, high-C-reactive protein, eosinopenia, and thrombocytopenia are associated with poor outcomes in AECOPD [19-21]. Although various scoring systems-such as St. George's Respiratory Questionnaire, mMRC, and CAT, are usefulpatients with severe symptoms may not be graded or might have similar scores, making them difficult to use. Instead, we focused on baseline spirometry and confirmed that $D_{L C O}$ is more accurate in evaluating the prognosis of hospitalized patients than $\mathrm{FEV}_{1}$. If a grading system that considers both $\mathrm{D}_{\mathrm{LCO}}$ and $\mathrm{FEV}_{1}$ is developed, the prognosis can be predicted more accurately.

Our study was limited because it was a retrospective single-center study. We were unable to analyze including important prognostic factors such as frequent exacerbations, obstructive sleep apnea, and body mass index. As this study is a retrospective study, data on these factors were not available or inaccurate. To compensate for this, we carefully analyzed the charts by two experienced pulmonologists. Also, we included as many factors as possible in baseline characteristics and multivariate analysis. In addition, the treatment received during the hospitalization period and the prognosis after discharge were not evaluated. Large prospective clinical studies that include information on treatment during hospitalization and postdischarge may be required.

\section{Conclusion}

$\mathrm{D}_{\mathrm{LCO}}$ was likely to be as good as or better as a prognostic marker than $\mathrm{FEV}_{1}$ in severe AECOPD. Accurate classification using $D_{\text {LCO }}$ may help to shorten hospital stay, reduce ICU experience, and improve 
prognosis.

\section{Abbreviations}

COPD: Chronic obstructive pulmonary disease

AECOPD: Acute exacerbation of chronic obstructive pulmonary disease

$D_{\text {LCO }}$ : Diffusing capacity of the lung for carbon monoxide

$\mathrm{FEV}_{1}$ : Forced expiratory volume in one second

\section{Declarations}

\section{Acknowledgments}

This study was supported by a Korea University Guro Hospital Grant (01801541)

\section{Author’s contributions}

Juwhan Choi performed data collection, interpretation and was major contributor in writing the manuscript. Jae Kyeom Sim, Jee Youn Oh, and Young Seok Lee performed data collection and interpretation. Gyu Young Hur, Sung Yong Lee, and Jae Jeong Shim performed data analysis and interpretation. Chin Kook Rhee and Kyung Hoon Min designed and supervised study. All authors have read and approved the manuscript.

\section{Funding}

Not applicable.

\section{Availability of data and materials}

The datasets used and/or analysed during the current study available from the corresponding author on reasonable request.

Ethics approval and consent to participate 
This study was conducted in accordance with the 'Declaration of Helsinki' as a statement of ethical principles for medical research involving human subjects, including the study of identifiable human substances and data. This study was approved by the Institutional Review Board of Korea University Guro Hospital (KUGH16131-002) for all research-related matters prior to the start of the study and was conducted in compliance with the relevant research regulations throughout the study. This study is a study through retrospective data analysis, and since there is no reason to estimate the subject's refusal to consent and the risk to the subject is low even without consent, it was approved as a 'signature consent waiver study' by the institutional review committee. In the course of the research, all personally identifiable data were anonymized to further minimize the impact on the research subject.

\section{Competing interests}

There is no competing interest. All authors declare they have no competing interest.

\section{Consent to publish}

Not applicable.

\section{References}

1. Leidy NK, Sexton CC, Jones PW, Notte SM, Monz BU, Nelsen L, Goldman M, Murray LT, Sethi S: Measuring respiratory symptoms in clinical trials of COPD: reliability and validity of a daily diary. Thorax 2014, 69(5):443-449.

2. Liu Y, Pleasants RA, Croft JB, Wheaton AG, Heidari K, Malarcher AM, Ohar JA, Kraft M, Mannino DM, Strange C: Smoking duration, respiratory symptoms, and COPD in adults aged $>/=45$ years with a smoking history. Int J Chron Obstruct Pulmon Dis 2015, 10:1409-1416.

3. Jones RL, Noble PB, Elliot JG, James AL: Airway remodelling in COPD: It's not asthma! Respirology 2016, 21(8):1347-1356.

4. Brusse-Keizer M, Klatte M, Zuur-Telgen M, Koehorst-Ter Huurne $K$, van der Palen J, VanderValk P: Comparing the 2007 and 2011 GOLD Classifications as Predictors of all-Cause Mortality and Morbidity in COPD. COPD 2017, 14(1):7-14.

5. Gruenberger JB, Vietri J, Keininger DL, Mahler DA: Greater dyspnea is associated with lower healthrelated quality of life among European patients with COPD. Int J Chron Obstruct Pulmon Dis 2017, 12:937-944.

6. Vogelmeier CF, Criner GJ, Martinez FJ, Anzueto A, Barnes PJ, Bourbeau J, Celli BR, Chen R, Decramer $M$, Fabbri LM et al: Global Strategy for the Diagnosis, Management and Prevention of Chronic Obstructive Lung Disease 2017 Report: GOLD Executive Summary. Respirology 2017, 22(3):575-601. 
7. Han MK, Muellerova H, Curran-Everett D, Dransfield MT, Washko GR, Regan EA, Bowler RP, Beaty TH, Hokanson JE, Lynch DA et al: GOLD 2011 disease severity classification in COPDGene: a prospective cohort study. Lancet Respir Med 2013, 1(1):43-50.

8. Jones PW: Health status and the spiral of decline. COPD 2009, 6(1):59-63.

9. Lee HY, Kim JW, Lee SH, Yoon HK, Shim JJ, Park JW, Lee JH, Yoo KH, Jung KS, Rhee CK: Lower diffusing capacity with chronic bronchitis predicts higher risk of acute exacerbation in chronic obstructive lung disease. J Thorac Dis 2016, 8(6):1274-1282.

10. Enright Md P: Office-based DLCO tests help pulmonologists to make important clinical decisions. Respir Investig 2016, 54(5):305-311.

11. Balasubramanian A, MacIntyre NR, Henderson RJ, Jensen RL, Kinney G, Stringer WW, Hersh CP, Bowler RP, Casaburi R, Han MK et al: Diffusing Capacity of Carbon Monoxide in Assessment of COPD. Chest 2019, 156(6):1111-1119.

12. Harvey BG, Strulovici-Barel Y, Kaner RJ, Sanders A, Vincent TL, Mezey JG, Crystal RG: Risk of COPD with obstruction in active smokers with normal spirometry and reduced diffusion capacity. Eur Respir J 2015, 46(6):1589-1597.

13. Liptay MJ, Basu S, Hoaglin MC, Freedman N, Faber LP, Warren WH, Hammoud ZT, Kim AW: Diffusion lung capacity for carbon monoxide (DLCO) is an independent prognostic factor for long-term survival after curative lung resection for cancer. J Surg Oncol 2009, 100(8):703-707.

14. Kim ES, Kim YT, Kang CH, Park IK, Bae W, Choi SM, Lee J, Park YS, Lee CH, Lee SM et al: Prevalence of and risk factors for postoperative pulmonary complications after lung cancer surgery in patients with early-stage COPD. Int J Chron Obstruct Pulmon Dis 2016, 11:1317-1326.

15. Diaz AA, Pinto-Plata V, Hernandez C, Pena J, Ramos C, Diaz JC, Klaassen J, Patino CM, Saldias F, Diaz O: Emphysema and DLCO predict a clinically important difference for 6MWD decline in COPD. Respir Med 2015, 109(7):882-889.

16. Grydeland TB, Thorsen E, Dirksen A, Jensen R, Coxson HO, Pillai SG, Sharma S, Eide GE, Gulsvik A, Bakke PS: Quantitative CT measures of emphysema and airway wall thickness are related to $D(L) C O$. Respir Med 2011, 105(3):343-351.

17. Chan HP, Mukhopadhyay A, Chong PL, Chin S, Wong XY, Ong V, Chan YH, Lim TK, Phua J: Role of $\mathrm{BMI}$, airflow obstruction, St George's Respiratory Questionnaire and age index in prognostication of Asian COPD. Respirology 2017, 22(1):114-119.

18. Martin AL, Marvel J, Fahrbach K, Cadarette SM, Wilcox TK, Donohue JF: The association of lung function and St. George's respiratory questionnaire with exacerbations in COPD: a systematic literature review and regression analysis. Respir Res 2016, 17:40.

19. Chang C, Zhu H, Shen N, Han X, Chen Y, He B: Utility of the combination of serum highly-sensitive Creactive protein level at discharge and a risk index in predicting readmission for acute exacerbation of COPD. J Bras Pneumol 2014, 40(5):495-503.

20. Rahimi-Rad MH, Asgari B, Hosseinzadeh N, Eishi A: Eosinopenia as a Marker of Outcome in Acute Exacerbations of Chronic Obstructive Pulmonary Disease. Maedica (Buchar) 2015, 10(1):10-13. 
21. Rahimi-Rad MH, Soltani S, Rabieepour M, Rahimirad S: Thrombocytopenia as a marker of outcome in patients with acute exacerbation of chronic obstructive pulmonary disease. Pneumonol Alergol Pol 2015, 83(5):348-351.

\section{Tables}

Table 1 Baseline characteristics of patients with AECOPD 


\begin{tabular}{|c|c|c|c|c|c|c|c|}
\hline & $\begin{array}{l}D_{\text {LCO }} \\
\text { Normal } \\
\text { group } \\
\left(D_{\text {LCO }}>\right. \\
50, n= \\
227)\end{array}$ & $\begin{array}{l}D_{\mathrm{LCO}} \\
\text { Impaired } \\
\text { group } \\
\left(D_{\mathrm{LCO}} \leq\right. \\
50, \mathrm{n}= \\
115)\end{array}$ & $\begin{array}{l}P \text { - } \\
\text { value }\end{array}$ & $\begin{array}{l}\text { FEV }_{1} \\
\text { Normal } \\
\text { group } \\
\left(\mathrm{FEV}_{1}>\right. \\
50, \mathrm{n}= \\
173)\end{array}$ & $\begin{array}{l}\mathrm{FEV}_{1} \\
\text { Impaired } \\
\text { group } \\
\left(\mathrm{FEV}_{1} \leq\right. \\
50, \mathrm{n}= \\
169)\end{array}$ & $\begin{array}{l}P \text { - } \\
\text { value }\end{array}$ & $\begin{array}{l}\text { Total } \\
(\mathrm{n}= \\
342)\end{array}$ \\
\hline Age $\left(\right.$ years) ${ }^{\dagger}$ & $\begin{array}{l}71.1 \pm \\
9.5\end{array}$ & $72.4 \pm 8.6$ & 0.223 & $\begin{array}{l}72.7 \pm \\
9.8\end{array}$ & $\begin{array}{l}70.4 \pm \\
8.5\end{array}$ & 0.023 & $\begin{array}{l}71.5 \pm \\
9.2\end{array}$ \\
\hline \multicolumn{8}{|l|}{$\begin{array}{l}\text { Sex, no. of } \\
\text { exacerbations }\end{array}$} \\
\hline Male $^{\ddagger}$ & $\begin{array}{l}144 \\
(63.4 \%)\end{array}$ & $\begin{array}{l}94 \\
(81.7 \%)\end{array}$ & 0.001 & $\begin{array}{l}105 \\
(60.7 \%)\end{array}$ & $\begin{array}{l}133 \\
(78.7 \%)\end{array}$ & $<0.001$ & $\begin{array}{l}238 \\
(69.6 \%)\end{array}$ \\
\hline Female $^{\ddagger}$ & $\begin{array}{l}83 \\
(36.6 \%)\end{array}$ & $\begin{array}{l}21 \\
(18.3 \%)\end{array}$ & & $\begin{array}{l}68 \\
(39.3 \%)\end{array}$ & $\begin{array}{l}36 \\
(21.3 \%)\end{array}$ & & $\begin{array}{l}104 \\
(30.4 \%)\end{array}$ \\
\hline \multicolumn{8}{|l|}{$\begin{array}{l}\text { Smoking history, } \\
\text { no. of } \\
\text { exacerbations }\end{array}$} \\
\hline Current smoker ${ }^{\ddagger}$ & $\begin{array}{l}42 \\
(18.5 \%)\end{array}$ & $\begin{array}{l}21 \\
(18.3 \%)\end{array}$ & 0.957 & $\begin{array}{l}32 \\
(18.5 \%)\end{array}$ & $\begin{array}{l}31 \\
(18.3 \%)\end{array}$ & 0.971 & $\begin{array}{l}63 \\
(18.4 \%)\end{array}$ \\
\hline Ex-smoker ${ }^{\ddagger}$ & $\begin{array}{l}185 \\
(81.5 \%)\end{array}$ & $\begin{array}{l}94 \\
(81.7 \%)\end{array}$ & & $\begin{array}{l}141 \\
(81.5)\end{array}$ & $\begin{array}{l}138 \\
(81.7 \%)\end{array}$ & & $\begin{array}{l}279 \\
(81.6 \%)\end{array}$ \\
\hline $\begin{array}{l}\text { Pack-year } \\
\text { history }^{\dagger}\end{array}$ & $\begin{array}{l}41.1 \pm \\
16.8\end{array}$ & $\begin{array}{l}41.8 \pm \\
17.9\end{array}$ & 0.446 & $\begin{array}{l}40.9 \pm \\
16.5\end{array}$ & $\begin{array}{l}41.7 \pm \\
17.8\end{array}$ & 0.987 & \\
\hline \multicolumn{8}{|l|}{$\begin{array}{l}\text { Comorbidities, no. } \\
\text { of exacerbations }\end{array}$} \\
\hline Hypertension ${ }^{\ddagger}$ & $\begin{array}{l}111 \\
(48.9 \%)\end{array}$ & $\begin{array}{l}53 \\
(46.1 \%)\end{array}$ & 0.623 & $\begin{array}{l}85 \\
(49.1 \%)\end{array}$ & $\begin{array}{l}79 \\
(46.7 \%)\end{array}$ & 0.659 & $\begin{array}{l}164 \\
(48.0 \%)\end{array}$ \\
\hline Diabetes $^{\ddagger}$ & $\begin{array}{l}54 \\
(23.8 \%)\end{array}$ & $\begin{array}{l}25 \\
(21.7 \%)\end{array}$ & 0.671 & $\begin{array}{l}43 \\
(24.9 \%)\end{array}$ & $\begin{array}{l}36 \\
(21.3 \%)\end{array}$ & 0.436 & $\begin{array}{l}49 \\
(23.1 \%)\end{array}$ \\
\hline $\begin{array}{l}\text { Previous TB } \\
\text { history }{ }^{\ddagger}\end{array}$ & $\begin{array}{l}58 \\
(25.6 \%)\end{array}$ & $\begin{array}{l}43 \\
(37.4 \%)\end{array}$ & 0.023 & $\begin{array}{l}35 \\
(20.2 \%)\end{array}$ & $\begin{array}{l}66 \\
(39.1 \%)\end{array}$ & $<0.001$ & $\begin{array}{l}101 \\
(29.5 \%)\end{array}$ \\
\hline $\begin{array}{l}\text { Coronary artery } \\
\text { disease }^{\ddagger}\end{array}$ & $\begin{array}{l}37 \\
(16.3 \%)\end{array}$ & $\begin{array}{l}17 \\
(14.8 \%)\end{array}$ & 0.716 & $\begin{array}{l}32 \\
(18.5 \%)\end{array}$ & $\begin{array}{l}22 \\
(13.0 \%)\end{array}$ & 0.165 & $\begin{array}{l}54 \\
(15.8 \%)\end{array}$ \\
\hline $\begin{array}{l}\text { Cerebrovascular } \\
\text { accident }^{\ddagger}\end{array}$ & $6(2.6 \%)$ & $9(7.8 \%)$ & 0.027 & $5(2.9 \%)$ & $10(5.9 \%)$ & 0.172 & $\begin{array}{l}15 \\
(4.4 \%)\end{array}$ \\
\hline \multicolumn{8}{|l|}{$\begin{array}{l}\text { Inhaler use before } \\
\text { admission }\end{array}$} \\
\hline & $2(0.9 \%)$ & $1(0.9 \%)$ & $\begin{array}{l}0.015 \\
\text { age } 12 / 19\end{array}$ & $2(1.2 \%)$ & $1(0.6 \%)$ & $<0.001$ & 3 \\
\hline
\end{tabular}




\begin{tabular}{|c|c|c|c|c|c|}
\hline LAMAs $^{\ddagger}$ & $\begin{array}{l}24 \\
(10.6 \%)\end{array}$ & $\begin{array}{l}14 \\
(12.2 \%)\end{array}$ & $\begin{array}{l}27 \\
(15.6 \%)\end{array}$ & $11(6.5 \%)$ & $\begin{array}{l}38 \\
(11.1 \%)\end{array}$ \\
\hline LABAs + LAMAs ${ }^{\ddagger}$ & $\begin{array}{l}36 \\
(15.9 \%)\end{array}$ & $\begin{array}{l}16 \\
(13.9 \%)\end{array}$ & $\begin{array}{l}24 \\
(13.9 \%)\end{array}$ & $\begin{array}{l}28 \\
(16.6 \%)\end{array}$ & $\begin{array}{l}52 \\
(15.2 \%)\end{array}$ \\
\hline ICS/LABAs ${ }^{\ddagger}$ & $\begin{array}{l}25 \\
(11.0 \%)\end{array}$ & $7(6.1 \%)$ & $\begin{array}{l}21 \\
(12.1 \%)\end{array}$ & $11(6.5 \%)$ & $\begin{array}{l}32 \\
(9.4 \%)\end{array}$ \\
\hline Triple therapy ${ }^{\ddagger}$ & $\begin{array}{l}53 \\
(23.3 \%)\end{array}$ & $\begin{array}{l}47 \\
(40.9 \%)\end{array}$ & $\begin{array}{l}32 \\
(18.5 \%)\end{array}$ & $\begin{array}{l}68 \\
(40.2 \%)\end{array}$ & $\begin{array}{l}100 \\
(29.2 \%)\end{array}$ \\
\hline None $^{\ddagger}$ & $\begin{array}{l}87 \\
(38.3 \%)\end{array}$ & $\begin{array}{l}30 \\
(26.1 \%)\end{array}$ & $\begin{array}{l}67 \\
(38.7 \%)\end{array}$ & $\begin{array}{l}50 \\
(29.6 \%)\end{array}$ & $\begin{array}{l}117 \\
(34.2 \%)\end{array}$ \\
\hline
\end{tabular}

Oral medication before admission

\begin{tabular}{|llllllll|}
$\begin{array}{l}\text { Oral } \beta 2 \\
\text { adrenoreceptor } \\
\text { agonist }^{\ddagger}\end{array}$ & $8(3.5 \%)$ & $\begin{array}{l}19 \\
(16.5 \%)\end{array}$ & $<0.001$ & $9(5.2 \%)$ & $\begin{array}{l}18 \\
(10.7 \%)\end{array}$ & 0.062 & $\begin{array}{l}27 \\
(7.9 \%)\end{array}$ \\
\hline Roflumilast $^{\ddagger}$ & $7(3.1 \%)$ & $10(8.7 \%)$ & 0.024 & $1(0.6 \%)$ & $16(9.5 \%)$ & $<0.001$ & $\begin{array}{l}17 \\
(5.0 \%)\end{array}$ \\
\hline Mucolytic agent $^{\ddagger}$ & $\begin{array}{l}92 \\
(40.5 \%)\end{array}$ & $\begin{array}{l}65 \\
(56.5 \%)\end{array}$ & 0.005 & $\begin{array}{l}68 \\
(43.3 \%)\end{array}$ & $\begin{array}{l}89 \\
(52.7 \%)\end{array}$ & 0.013 & $\begin{array}{l}157 \\
(45.9 \%)\end{array}$ \\
\hline Oral steroids $^{\ddagger}$ & $6(2.6 \%)$ & $2(1.7 \%)$ & 0.722 & $2(1.2 \%)$ & $6(3.6 \%)$ & 0.170 & $\begin{array}{l}8 \\
(2.3 \%)\end{array}$ \\
\hline Oral antibiotics $^{\ddagger}$ & $7(3.1 \%)$ & $4(3.5 \%)$ & 1.000 & $3(1.7 \%)$ & $8(4.7 \%)$ & 0.116 & 11 \\
& & & & & & & $(3.2 \%)$
\end{tabular}

Baseline spirometry

\begin{tabular}{|c|c|c|c|c|c|c|c|}
\hline $\mathrm{FEV}_{1}(\text { liters })^{\dagger}$ & $1.5 \pm 0.5$ & $1.1 \pm 0.4$ & $<0.001$ & $1.6 \pm 0.5$ & $1.0 \pm 0.3$ & $<0.001$ & $\begin{array}{l}1.3 \pm \\
0.5\end{array}$ \\
\hline 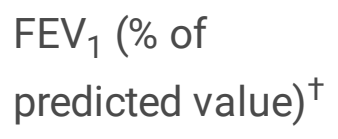 & $\begin{array}{l}59.9 \pm \\
18.1\end{array}$ & $\begin{array}{l}42.1 \pm \\
16.0\end{array}$ & $<0.001$ & $\begin{array}{l}69.5 \pm \\
13.6\end{array}$ & $\begin{array}{l}38.0 \pm \\
8.1\end{array}$ & $<0.001$ & $\begin{array}{l}54.0 \pm \\
19.3\end{array}$ \\
\hline $\mathrm{D}_{\mathrm{LCO}}(\text { liters })^{\dagger}$ & $\begin{array}{l}12.5 \pm \\
5.0\end{array}$ & $6.6 \pm 2.2$ & $<0.001$ & $\begin{array}{l}11.9 \pm \\
5.3\end{array}$ & $8.9 \pm 4.1$ & $<0.001$ & $\begin{array}{l}10.6 \pm \\
5.1\end{array}$ \\
\hline 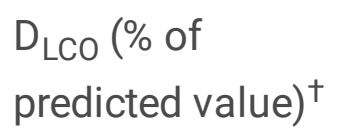 & $\begin{array}{l}73.5 \pm \\
16.4\end{array}$ & $38.7 \pm 8.8$ & $<0.001$ & $\begin{array}{l}71.4 \pm \\
20.4\end{array}$ & $\begin{array}{l}52.0 \pm \\
18.7\end{array}$ & $<0.001$ & $\begin{array}{l}61.8 \pm \\
21.8\end{array}$ \\
\hline
\end{tabular}

${ }^{\dagger}$ Numbers are presented as mean \pm standard deviation.

${ }^{\ddagger}$ Numbers are presented as $\mathrm{n}(\%)$ 
Abbreviations: AECOPD, acute exacerbations of chronic obstructive pulmonary disease; LABAs, long acting $B$ agonist bronchodilator; LAMAs, long acting antimuscarinic agent bronchodilator; ICS, inhaled corticosteroids; $\mathrm{FEV}_{1}$, forced expiratory volume in one second; $\mathrm{D}_{\mathrm{LCO}}$, diffusing capacity of the lung for carbon monoxide

Table 2 Prognosis analysis for severe AECOPD

\begin{tabular}{|c|c|c|c|c|c|c|}
\hline \multirow{3}{*}{ Parameter } & \multicolumn{3}{|c|}{ Univariate analysis } & \multicolumn{3}{|c|}{ Multivariate analysis } \\
\hline & $\begin{array}{l}\mathrm{D}_{\mathrm{LCO}} \text { Normal } \\
\text { group }\end{array}$ & $\begin{array}{l}\mathrm{D}_{\mathrm{LCO}} \text { Impaired } \\
\text { group }\end{array}$ & $\begin{array}{l}P \text { - } \\
\text { value }\end{array}$ & $\begin{array}{l}\text { Odds } \\
\text { ratio }\end{array}$ & $\begin{array}{l}95 \% \text { confidence } \\
\text { interval }\end{array}$ & $\begin{array}{l}P \text { - } \\
\text { value }\end{array}$ \\
\hline & $\begin{array}{l}\left(D_{\text {LCO }}>50, n\right. \\
=227)\end{array}$ & $\begin{array}{l}\left(D_{\text {LCO }} \leq 50, n\right. \\
=115)\end{array}$ & & & & \\
\hline $\begin{array}{l}\text { Mortality in } \\
\text { hospital }\end{array}$ & $3(1.3 \%)$ & $8(7.0 \%)$ & 0.008 & 4.408 & $1.070-18.167$ & 0.040 \\
\hline $\begin{array}{l}\text { Mechanical } \\
\text { ventilation } \neq\end{array}$ & $11(4.8 \%)$ & $19(15.7 \%)$ & 0.001 & 2.855 & $1.216-6.704$ & 0.016 \\
\hline \multirow{3}{*}{$\begin{array}{l}\text { Intensive care } \\
\text { unit }{ }^{\ddagger}\end{array}$} & $16(7.0 \%)$ & $23(20.0 \%)$ & $<0.001$ & 2.685 & $1.290-5.590$ & 0.008 \\
\hline & $\begin{array}{l}\text { FEV }_{1} \text { Normal } \\
\text { group }\end{array}$ & $\begin{array}{l}\text { FEV }_{1} \text { Impaired } \\
\text { group }\end{array}$ & & & & \\
\hline & $\begin{array}{l}\left(\mathrm{FEV}_{1}>50, \mathrm{n}\right. \\
=173)\end{array}$ & $\begin{array}{l}\left(\mathrm{FEV}_{1} \leq 50, \mathrm{n}\right. \\
=169)\end{array}$ & & & & \\
\hline $\begin{array}{l}\text { Mortality in } \\
\text { hospital }\end{array}$ & $3(1.7 \%)$ & $8(4.7 \%)$ & 0.116 & 4.633 & $0.858-25.036$ & 0.075 \\
\hline $\begin{array}{l}\text { Mechanical } \\
\text { ventilation } \neq\end{array}$ & $7(4.0 \%)$ & $22(13.0 \%)$ & 0.003 & 3.518 & $1.335-9.270$ & 0.011 \\
\hline $\begin{array}{l}\text { Intensive care } \\
\text { unit }{ }^{\ddagger}\end{array}$ & $9(5.2 \%)$ & $30(17.8 \%)$ & $<0.001$ & 4.527 & $1.886-10.869$ & 0.001 \\
\hline
\end{tabular}

${ }^{\dagger}$ Numbers are presented as mean \pm standard deviation

${ }^{\ddagger}$ Numbers are presented as $\mathrm{n}(\%)$

Multivariate analysis was conducted for variables with a $P$-value of less than 0.05 in the univariate analysis, except for baseline spirometry. 
Abbreviations: AECOPD, acute exacerbations of chronic obstructive pulmonary disease; FEV ${ }_{1}$, forced expiratory volume in one second; $D_{\mathrm{LCO}}$, diffusing capacity of the lung for carbon monoxide

Table 3 Correlation analysis of length of hospital stay

\begin{tabular}{|c|c|c|c|c|c|c|}
\hline \multirow[b]{2}{*}{ Group } & \multirow[b]{2}{*}{$\begin{array}{l}\text { Number of } \\
\text { events }\end{array}$} & \multirow[b]{2}{*}{$\begin{array}{l}\text { Length of } \\
\text { hospital stay } \\
\text { (days) }^{\dagger}\end{array}$} & \multicolumn{2}{|l|}{ Univariate } & \multicolumn{2}{|c|}{ Multivariate } \\
\hline & & & $\begin{array}{l}\text { Correlation } \\
\text { coefficient }\end{array}$ & $\begin{array}{l}P \text { - } \\
\text { value }\end{array}$ & $B$ & $\begin{array}{l}P \text { - } \\
\text { value }\end{array}$ \\
\hline $\begin{array}{l}D_{\text {LCO }} \text { Normal group } \\
\left(D_{\text {LCO }}>50\right)\end{array}$ & 227 & $7.3 \pm 5.0$ & -0.112 & $<0.001$ & -0.103 & $<0.001$ \\
\hline $\begin{array}{l}D_{\text {LCO }} \text { Impaired } \\
\text { group }\left(D_{\text {LCO }} \leq 50\right)\end{array}$ & 115 & $12.4 \pm 13.2$ & & & & \\
\hline $\begin{array}{l}\text { FEV }_{1} \text { Normal } \\
\text { group }\left(\mathrm{FEV}_{1}>50\right)\end{array}$ & 173 & $7.7 \pm 5.4$ & -0.082 & 0.001 & -0.075 & 0.007 \\
\hline $\begin{array}{l}\mathrm{FEV}_{1} \mathrm{Impaired} \\
\text { group }\left(\mathrm{FEV}_{1} \leq 50\right)\end{array}$ & 169 & $10.4 \pm 11.4$ & & & & \\
\hline
\end{tabular}

${ }^{\dagger}$ Numbers are presented as mean \pm standard deviation.

Multivariate analysis was conducted for variables with a $P$-value of less than 0.05 in the univariate analysis, except for baseline spirometry.

$B$ is the regression coefficient, and the negative sign of the regression coefficient means that the variables are negatively associated.

Abbreviations: $\mathrm{FEV}_{1}$, forced expiratory volume in one second; $\mathrm{D}_{\mathrm{LCO}}$, diffusing capacity of the lung for carbon monoxide

Table 4 ROC curve analysis of $\mathrm{D}_{\mathrm{LCO}}$ and $\mathrm{FEV}_{1}$ 


\begin{tabular}{|c|c|c|c|c|c|c|}
\hline Parameter & $\begin{array}{l}\text { Prognostic } \\
\text { factor }\end{array}$ & $\begin{array}{l}\text { Optimal cut- } \\
\text { off }\end{array}$ & Sensitivity & Specificity & AUC & $\begin{array}{l}P \text { - } \\
\text { value }\end{array}$ \\
\hline $\begin{array}{l}\text { Mortality in } \\
\text { hospital }\end{array}$ & $\mathrm{D}_{\mathrm{LCO}}$ & 48.5 & 71.0 & 72.7 & 0.827 & $<0.001$ \\
\hline $\begin{array}{l}\text { Mortality in } \\
\text { hospital }\end{array}$ & $\mathrm{FEV}_{1}$ & 45.5 & 63.1 & 63.6 & 0.621 & 0.173 \\
\hline $\begin{array}{l}\text { Mechanical } \\
\text { ventilation }\end{array}$ & $\mathrm{D}_{\mathrm{LCO}}$ & 51.5 & 68.4 & 65.5 & 0.717 & $<0.001$ \\
\hline $\begin{array}{l}\text { Mechanical } \\
\text { ventilation }\end{array}$ & $\mathrm{FEV}_{1}$ & 44.5 & 66.5 & 65.5 & 0.675 & 0.002 \\
\hline Intensive care unit & $\mathrm{D}_{\mathrm{LCO}}$ & 53.5 & 65.0 & 64.1 & 0.682 & $<0.001$ \\
\hline Intensive care unit & $\mathrm{FEV}_{1}$ & 46.5 & 63.0 & 64.1 & 0.652 & 0.002 \\
\hline
\end{tabular}

Abbreviations: ROC, receiver operating characteristics; AUC, area under the curve; FEV 1 , forced expiratory volume in one second; $D_{L C O}$, diffusing capacity of the lung for carbon monoxide

Figures

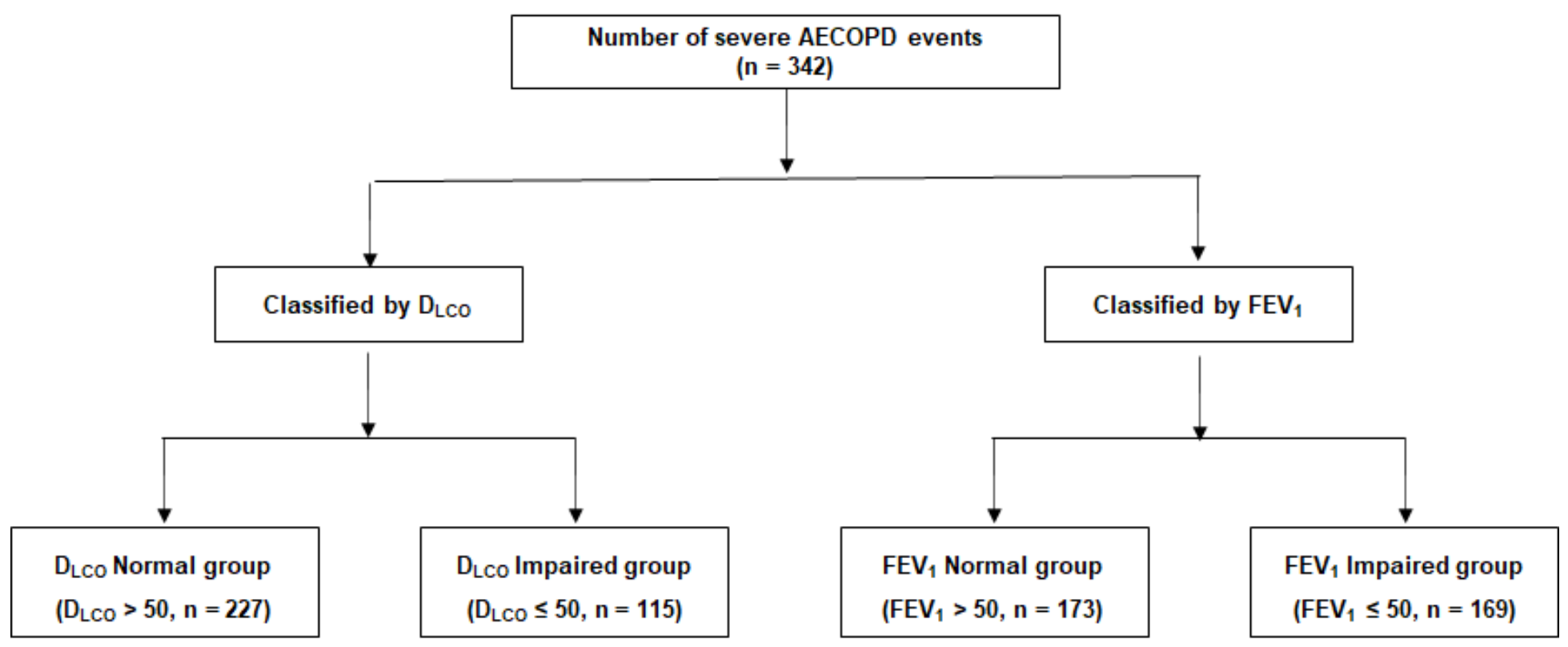

Figure 1

Study design 
(A)

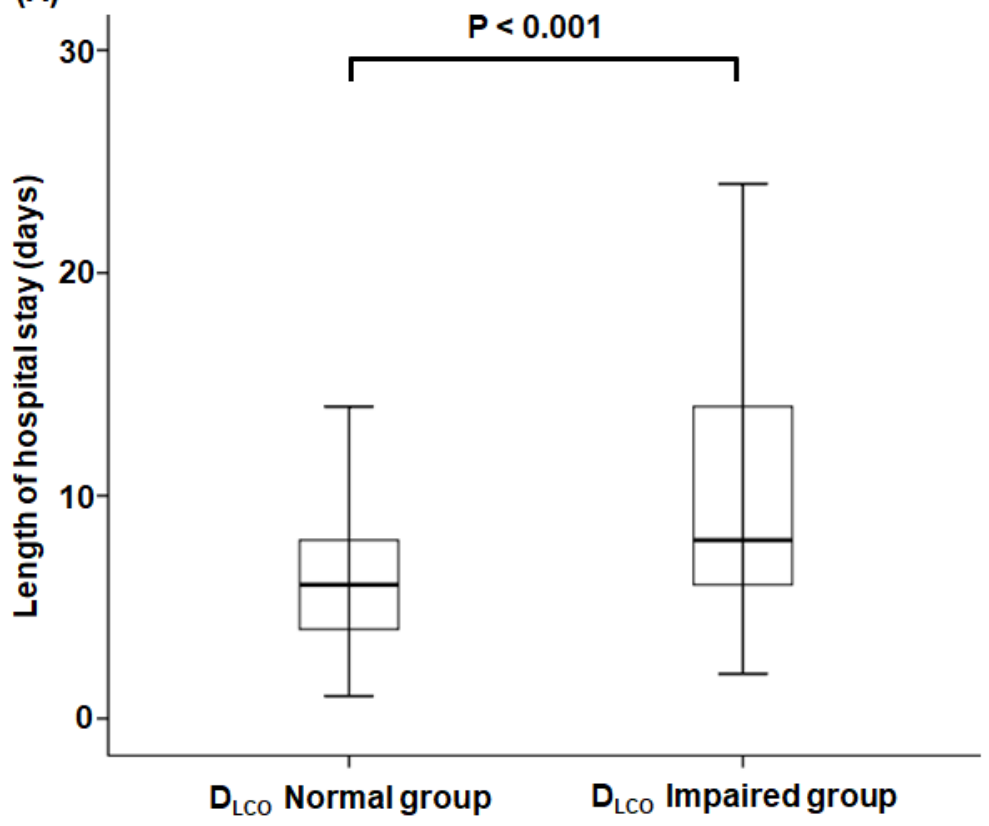

( $n=227)$

(C)

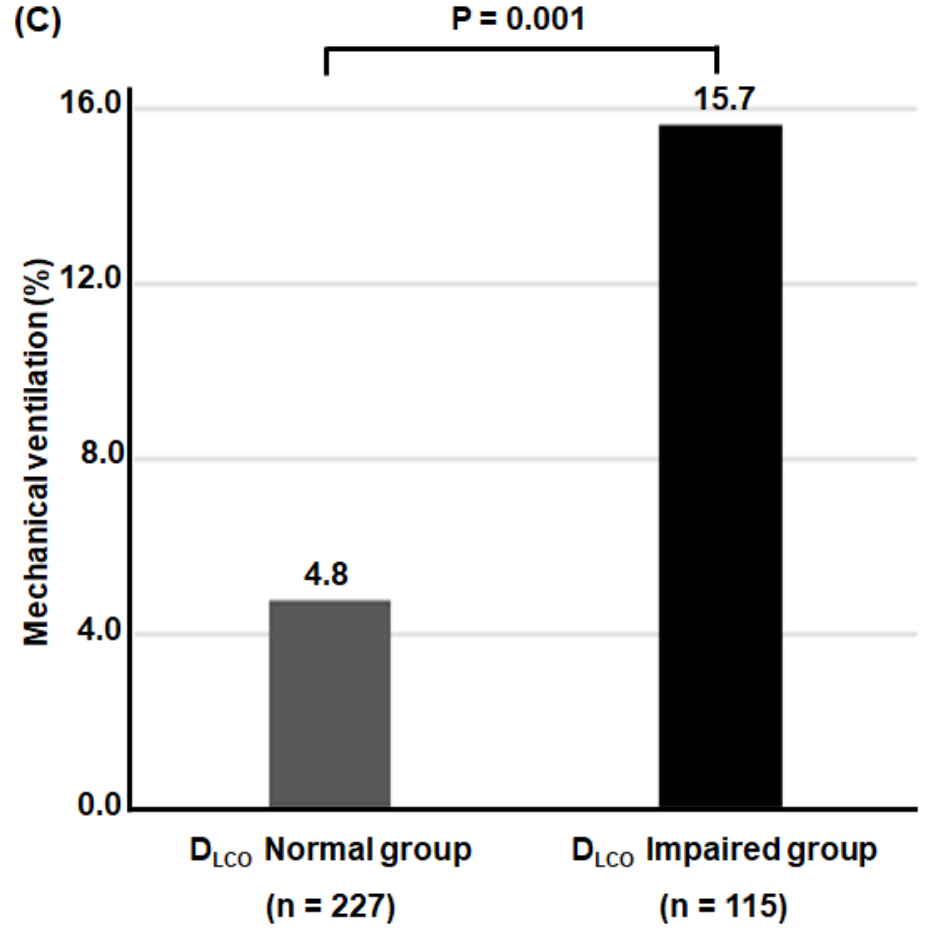

(B)

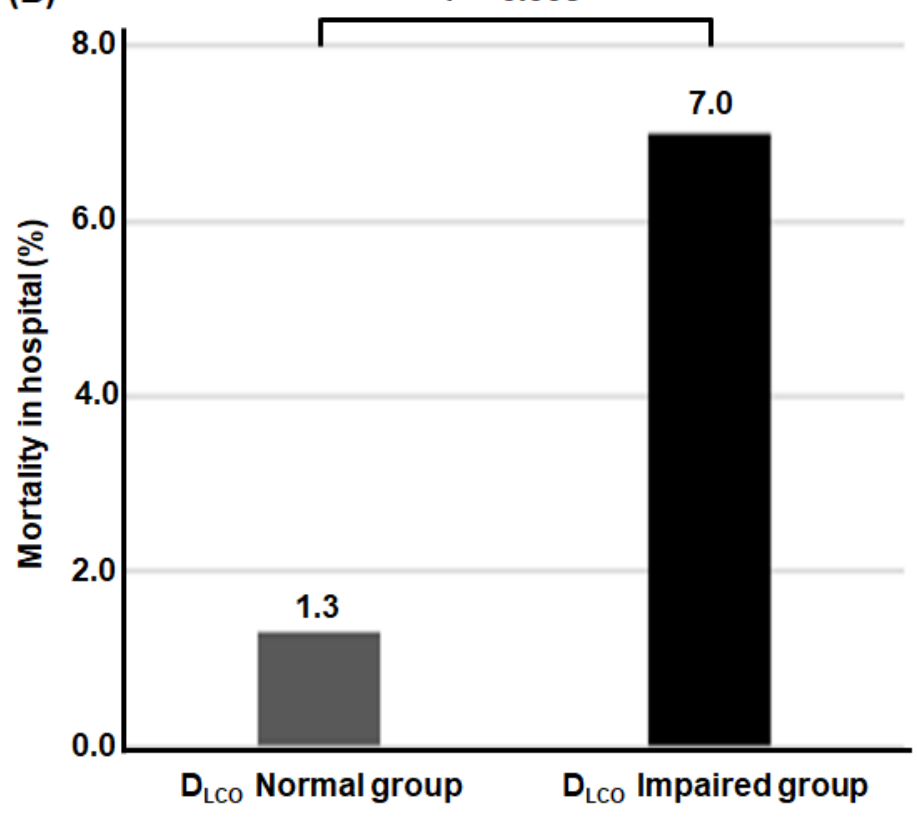

( $n=227$ )

( $n=115$ )

(D)
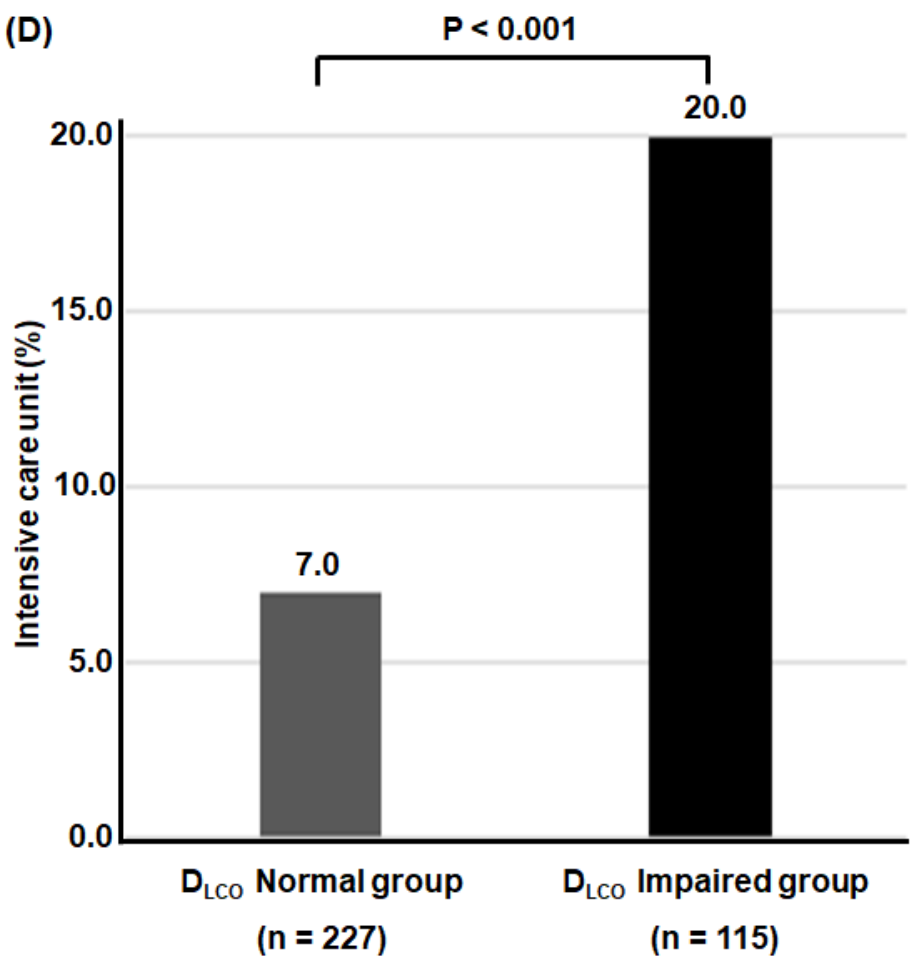

Figure 2

Prognosis analysis for severe AECOPD according to DLCO classification (A) Length of hospital stay (days), (B) mortality in hospital, (C) mechanical ventilation, and (D) intensive care unit AECOPD, acute exacerbations of chronic obstructive pulmonary disease; DLCO, diffusing capacity of the lung for carbon monoxide 
(A)

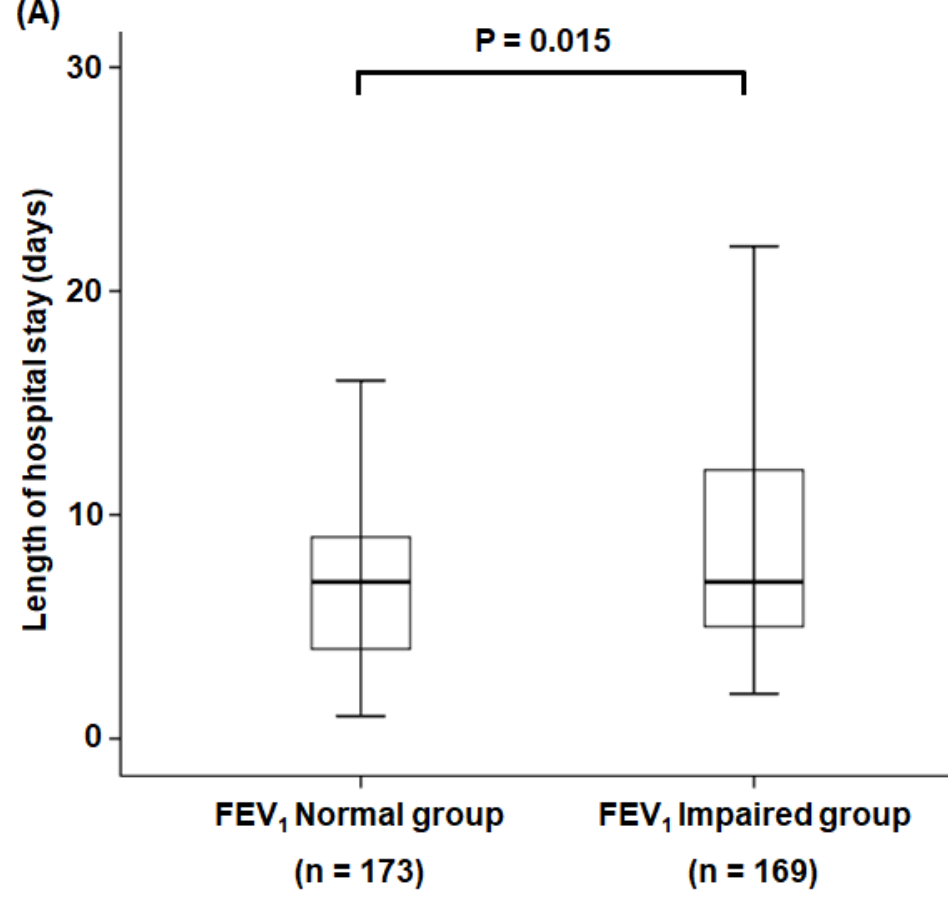

(C)

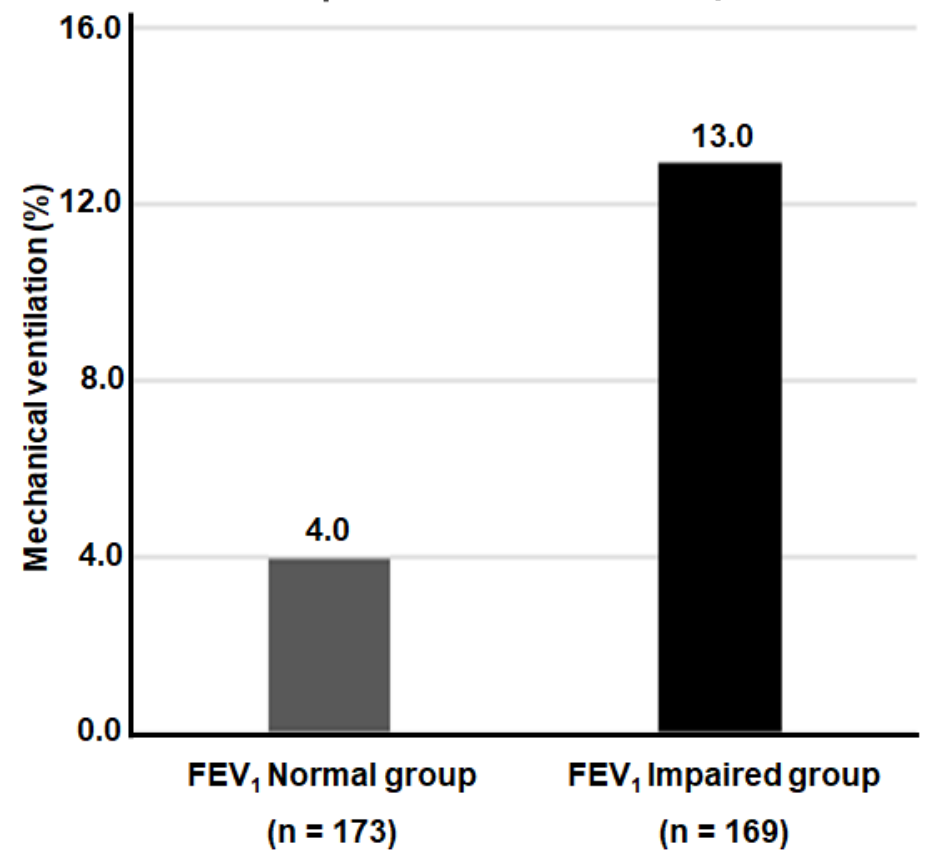

(B)

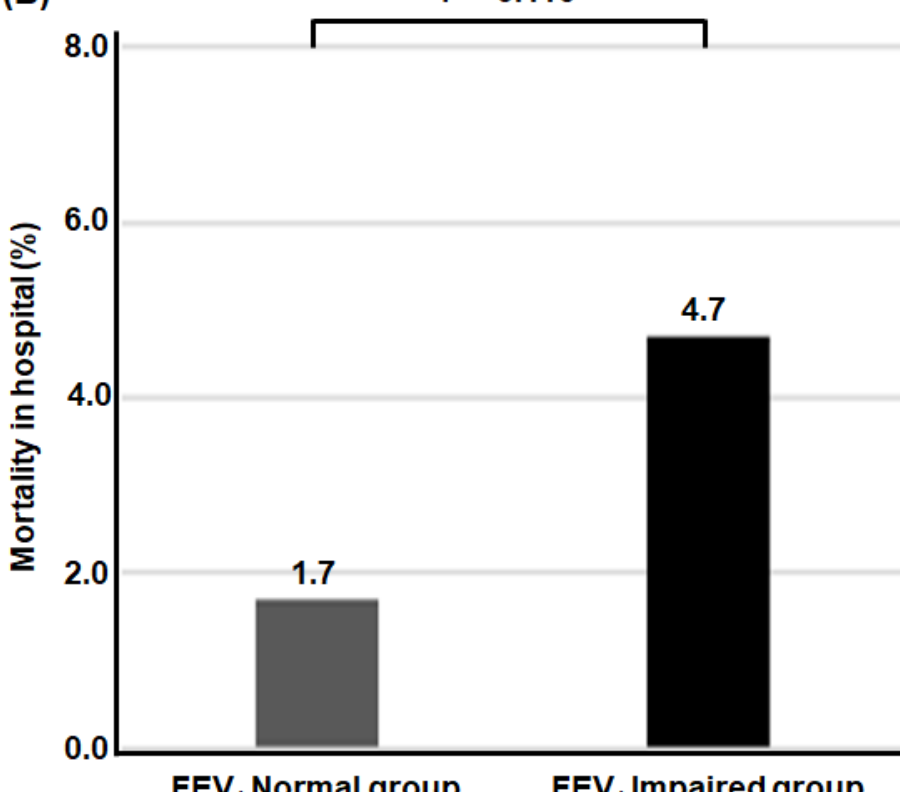

FEV $_{1}$ Normal group

( $n=173$ )

( $n=169$ )

(D)
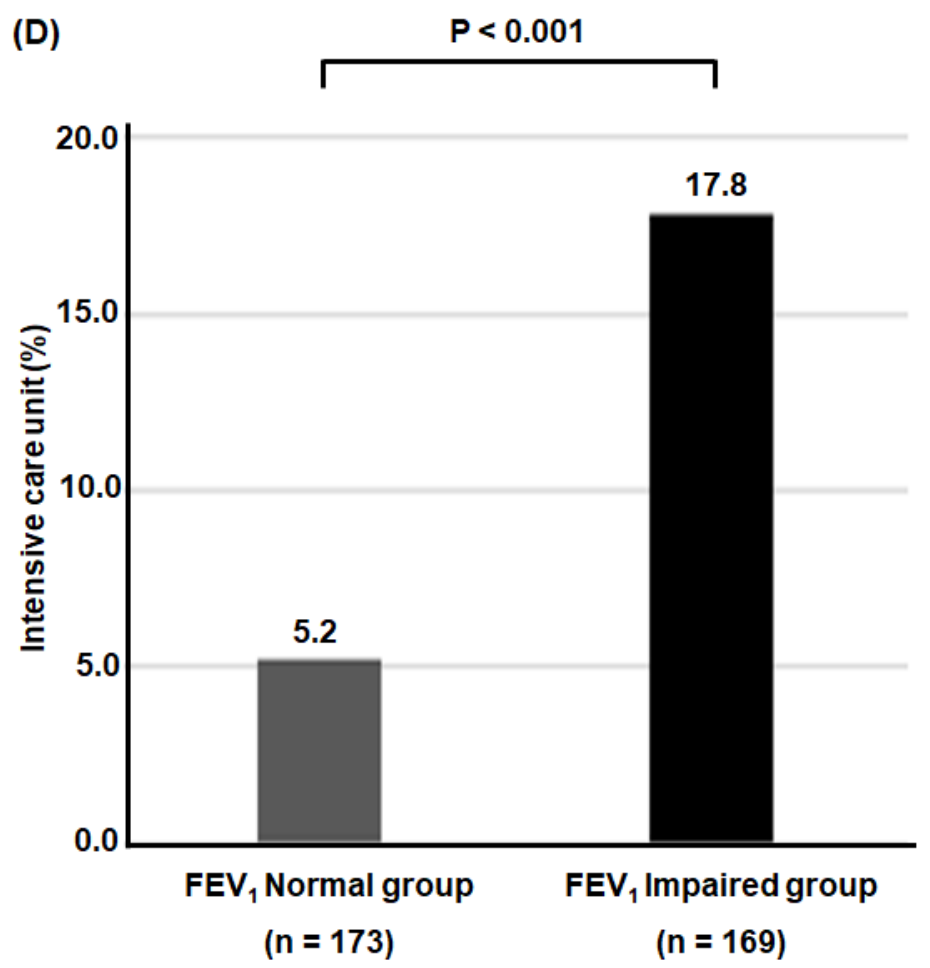

Figure 3

Prognosis analysis for severe AECOPD according to FEV1 classification (A) Length of hospital stay (days), (B) mortality in hospital, (C) mechanical ventilation, and (D) intensive care unit AECOPD, acute exacerbations of chronic obstructive pulmonary disease; FEV1, forced expiratory volume in one second 


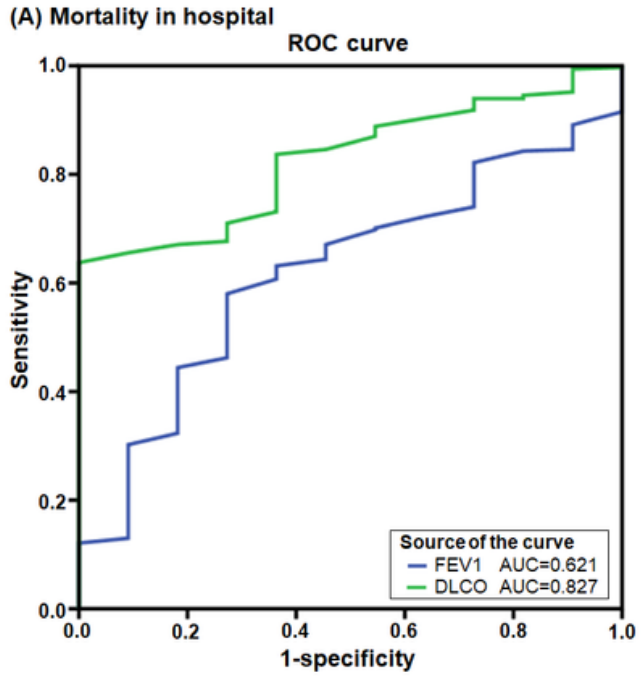

(B) Mechanical ventilation

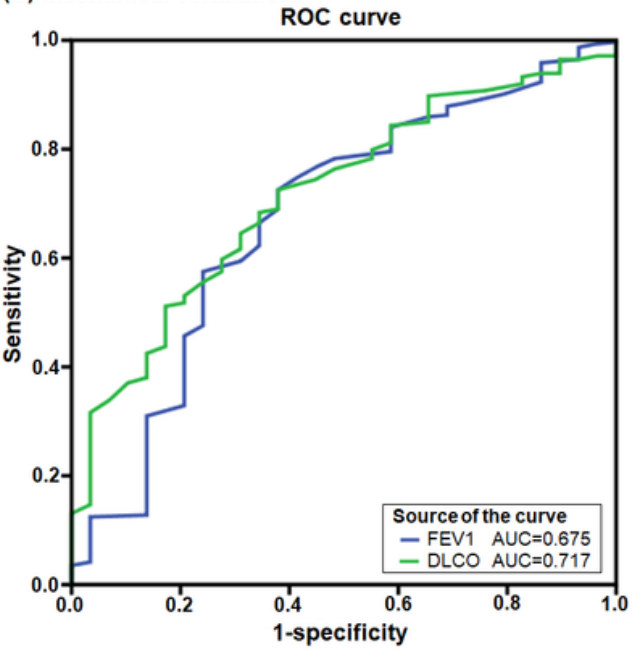

(C) Intensive care unit

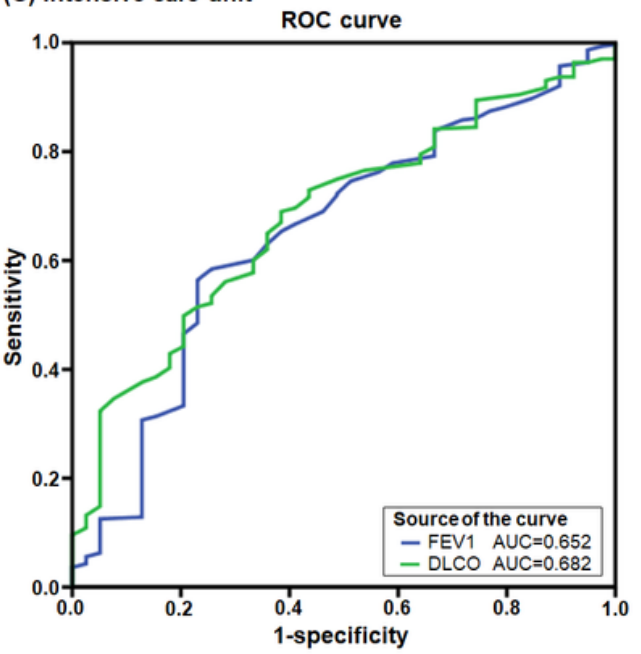

Figure 4

ROC curve of DLCO and FEV1 (A) Mortality in hospital, (B) mechanical ventilation, and (C) intensive care unit ROC, receiver operating characteristics; FEV1, forced expiratory volume in one second; DLCO, diffusing capacity of the lung for carbon monoxid 